\title{
The assessment of the protein profiles and oxidant/antioxidant status in conjunctival Brucella melitensis Rev.1 vaccinated sheep
}

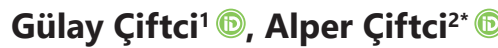 \\ ${ }^{a}$ Department of Biochemistry, Faculty of Veterinary Medicine, University of Ondokuz Mayis, Atakum, Samsun, Turkey. \\ ${ }^{b}$ Department of Microbiology, Faculty of Veterinary Medicine, University of Ondokuz Mayis, Atakum, Samsun, Turkey.
}

Geliş Tarihi / Received: 07.05.2021, Kabul Tarihi / Accepted: 08.07.2021

\begin{abstract}
Brucellosis is a zoonotic and economically significant animal disease worldwide. The most frequently used vaccine to avoid brucellosis in small ruminants is the Rev.1 conjunctival Brucella melitensis vaccine. The aim of this study was to investigate the effects of B.melitensis Rev. 1 conjunctival vaccine on total protein, albumin, globulin levels, protein profiles and oxidant/antioxidant status in sheep. Ten sheep were used as animal material for this purpose. The bloods taken before vaccination were used as negative control. The sera obtained one month after administration of single dose B.melitensis vaccine were used as experimental materials. The spectrophotometric method estimated total protein, albumin, globulin levels, total antioxidant capacity (TAS), and total oxidant capacity (TOS). Protein profile was determined by sodium-dodecyl-sulphate and native-polyacrylamide gel electrophoresis methods. It was determined that total protein and globulin levels increased slightly in sero positive sheep $(P>0.05)$. There was no difference for protein profiles in both electrophoresis methods. The band densities of albumin decreased but gamma globulin increased slightly after vaccination. TAS levels decreased significantly $(P<0.05)$, but TOS levels increased slightly $(\mathrm{P}>0.05)$. In conclusion, Rev.1 conjunctival Brucella vaccine was thought to be safe to use to prevent Brucellosis, and the addition of antioxidant after vaccination can reduce oxidative stress.
\end{abstract}

Keywords: Brucella melitensis Rev.1, Conjunctival vaccine, Oxidative stress, Protein profile.

\section{Konjunktival Brucella melitensis Rev.1 ile aşılanmış koyunlarda protein profillerinin ve oksidan/antioksidan durumunun değerlendirilmesi}

\begin{abstract}
Özet: Bruselloz, dünya çapında zoonotik ve ekonomik açıdan önemli bir hayvan hastalığıdır. Küçükbaş hayvanlarda brusellozdan korunmak için en sık kullanılan aşı Rev.1 konjunktival Brucella melitensis aşısıdır. Bu çalışmanın amacı, koyunlarda B. melitensis Rev.1 konjunktival aşısının total protein, albümin, globulin düzeyleri, protein profilleri ve oksidan/antioksidan durumuna etkilerini araştırmaktır. Bu amaçla hayvan materyali olarak on koyun kullanıldı. Aşılama öncesi alınan kanlar negatif kontrol olarak kullanıldı. Tek doz B. melitensis aşısının uygulanmasından bir ay sonra elde edilen serumlar deney materyali olarak kullanıldı. Total protein, albümin, globulin seviyeleri ile antioksidan kapasite (TAS) ve oksidan kapasiteyi (TOS) spektrofotometrik yöntem ile belirlendi. Protein profili, sodyum-dodesilsülfat ve natif-poliakrilamid jel elektroforez yöntemleri ile belirlendi. Sero-pozitif koyunlarda total protein ve globulin düzeylerinin hafif yükseldiği belirlendi $(P>0,05)$. Her iki elektroforez yönteminde de protein profilleri açısından fark bulunmadı. Aşılamadan sonra albüminin bant yoğunluklarının azaldığı, ancak gama-globülin yoğunluklarının hafifçe artmış olduğu tespit edildi. TAS düzeyleri önemli ölçüde azalmışken $(P<0,05)$, TOS düzeylerinde biraz artış gözlendi $(P>0,05)$. Sonuç olarak, Rev.1 konjunktival Brucella aşısının Brucellozdan korunmak için kullanımının güvenli olduğu ve aşılamadan sonra rasyona antioksidan eklenmesinin oksidatif stresi azaltabileceği düşünüldü.
\end{abstract}

Anahtar kelimeler: Brucella melitensis Rev.1, Konjunktival aşı, Oksidatif stres, Protein profili.

\section{Introduction}

Brucellosis is a significant contagious bacterial infection in animals worldwide, and a potential zoonotic disease. In general, the disease can cause significant productivity loss through abortion, stillbirth, low herd fertility and low milk production (Diaz Aparicio 2013). Control and eradication programs are implemented in many countries where brucellosis is observed. Many countries where brucellosis is detected adopt control and eradication programs (Revappayya et al. 2017). In this way it seeks to reduce animal infection and mitigate the impact of the disease on human health as well as on animal health and development, and the other step involves steps to avoid the reappearance of the disease (Kaplan 1966; Alton and Elberg 1967; WHO 1986; Blasco 1997). The most widely used vaccine for the prevention of brucellosis in sheep and goats is the B. melitensis Rev.1 vaccine (Marzetti et al. 2013; Shome et al. 2014). 
There is a balance between the development of free radicals and enzymatic and non-enzymatic antioxidant defense mechanisms in the animal body (Hornback and Roop 2006). Due to normal aerobic metabolism, reactive oxygen species (ROS) can be produced in all living organisms, and their levels increase during infection. One of the essential molecules that destroy bacteria in phagocytic cells such as macrophages and polymorphonic neutrophils (PMNs) is the reactive oxygen species (Dieffenbach and Tramont 2005). They settle in phagocytic cells and release phagosomes upon the growth of bacteria (Rada et al. 2008). They cause cell damage by peroxidation in DNA, protein and fatty acids (Orem et al. 1997; Halliwell and Gutteridge 1999). Reactive oxygen species, such as superoxide, hydrogen peroxide and hydroxyl radical are released by neutrophils and have been shown to play an important role in inflammation, and cell injury (Vladimirov 2004). Brucella infection induced oxidative stress and lipid peroxidation in human, cattle and rats (Erdogan et al. 2007; Nisbet et al. 2007). Cytotoxic effects of oxidants include protein oxidation, lipid peroxidation, DNA damage and the inhibition of cellular metabolic pathways (Kim et al. 2006). Cells and tissues have antioxidant systems that inhibit radical products and reactions. Studies have demonstrated altered total oxidant (TOC) and total antioxidant capacity (TAC), or oxidative stress index (OSI) in case of local and systemic inflammation or infection (Usta et al. 2012; Celi and Gabai 2015; Oral et al. 2015).

Sodium dodecyl sulphate polyacrylamide gel electrophoresis (SDS-PAGE) is a versatile and powerful technique widely used for protein separation based on their molecular weights (Laemmli 1970). In this study protein fractions were evaluated by SDS-PAGE and Native-PAGE due to its importance in the resolution of serum proteins. Determination of albumin and/or globulin concentrations by serum protein electrophoresis in domestic animals is an important diagnostic method. Determination of the total oxidant and antioxidant level and protein profile helps in the evaluation and diagnosis of the disease process along with other clinical and laboratory studies. For this purpose, it was aimed to determine the effects of Rev.1 conjunctival Brucella vaccine on sheep protein protein profile, total oxidant/antioxidant levels and oxidative stress index.

\section{Materials and Methods}

\section{Experimental animals}

Ten 5-months-old female Karayaka sheep, known to be unvaccinated, were used in the study. The group from which blood was collected from Vena jugularis before vaccination formed the control group. The experimental group consisted of animals from which blood was collected one month after vaccination. The vaccine, which was supplied lyophilized, was homogenized by melting it with a dilution liquid colored with Patent Blue V. 5-month-old female Karayaka sheep was applied as $40 \pm 2 \mu$ ( 1 drop) by installing a dropper in the bottle containing the reconstituted vaccine. The vaccine was administered in a single dose. After vaccination, blood was collected from Vena Jugularis (Çiftci et al. 2019).

Blood samples taken into anti-coagulated tubes were centrifuged at $1550 \mathrm{~g}$ and $4^{\circ} \mathrm{C}$ for 10 minutes to collect the serums to be used in the experiments. The clear blood serum on top was taken into plastic vials and kept at $-80^{\circ} \mathrm{C}$ until analysis was performed.

\section{Serological analysis}

Rose Bengal (RB) Plate Test for the presence of specific antibodies and Standard Tube Aglutination (STAT) test for the determination of specific antibody titers were applied to the sera obtained from blood taken before and after vaccination (Çiftci et al. 2019).

\section{Biochemical analysis}

Total protein, globulin and albumin levels in sheep were measured by serum biochemistry autoanalysers (Autolab, AMS srl, Aotu analyzer, Netherlands) using commercial autoanalyzer test kits (Audit Diagnostics, Ireland).

\section{Serum total antioxidant, total oxidant level measurement and Oxidative Stress Index}

Total antioxidant status (TAS) was measured using commercial kits (Rel Assay Kit Diagnostics, Turkey) (Erel 2005). Results are expressed as mmol Trolox equiv/lt.

Total oxidant status (TOS) was measured using commercial kits (Rel Assay Kit Diagnostics, Turkey) (Erel 2004). Results are presented as $\mu \mathrm{mol} \mathrm{H}_{2} \mathrm{O}_{2}$ equiv/lt.

The calculation of the OSI was expressed as the percentage of the ratio of TOS levels to TAS levels, the $\mathrm{mmol}$ value in the unit of the TAS test was converted to $\mu \mathrm{mol}$ as in the TOS test (Erel 2004). The results 
are presented as "arbitrary unit" (AU) and calculated according to the formula [OSI $=\left(T O S ; \mu \mathrm{mol} \mathrm{H}_{2} \mathrm{O}_{2}\right.$ equiv/lt)/(TAS, mmol Trolox equiv/lt) $x$ 10]

\section{Serum protein profile}

The serum protein profiles of the sera which were obtained before and one month after vaccination were determined by Native- and SDS-PAGE methods as described by Laemmli (1970). Protein concentration in the serum was measured by spectrophotometric method before electrophoresis with a nano-drop spectrophotometer.

Serum protein electrophoresis was used for the determination of albumin, alpha-1 globulin, alpha-2 globulin, beta globulin and gamma globulin (Parish and Marchalonis 1970). For this aim, twenty $\mu \mathrm{l}$ of sample was loaded on the separation gel (4\%). Proteins were separated in $10 \%$ Native-PAGE gel with a $100 \mathrm{~V}$ for $90 \mathrm{~min}$. The gel was stained with the Blue silver method (Candiano et al. 2004). The serum proteins were differentiated SDS-by PAGE $(7.5 \mu$ l acrylamide $+10 \%$ SDS, $20 \mu$ sample, $200 \mathrm{~V}$ and $150 \mathrm{~mA}$, about $60 \mathrm{~min}$ ) according to molecular weights (Laemmli 1970). After electrophoresis, the bands were stained with the Blue silver method. The molecular weights of the protein profile were calculated using the Kodak Molecular Image Analysis Software program.

\section{Statistical analysis}

SPSS statistical software v.21 (IBM Corp., Armonk, NY) was used for statistical analysis. Pairent samples $T$ test was used to determine the variations among the parameters examined in the groups.

\section{Results}

\section{Serological analysis results}

All sera from blood taken before the vaccination gave negative RBPT results, while all sera from the experimental groups $(n=10)$ gave positive reactions.

Serum antibody titers were determined as a result of STAT performed on 10 sera with positive reaction after RBPT. The titers were varied between $1 / 20-1 / 80$. The mean titer of STAT results was calculated as $1 / 36$. According to the STAT results, the antibody titer increased significantly $(p<0.001)$ at 1 month after vaccination compared to the prevaccination sera.

\section{Biochemical parameter results}

The concentrations of total protein, albumin and globulin in sheep before and after vaccination were $6.79 \pm 0.18$ and $7.13 \pm 0.23,3.65 \pm 0.08$ and $3.51 \pm 0.008$, $3.19 \pm 0.18$ and $3.63 \pm 0.2$, respectively (Figure 1 ). It was determined that the amount of total protein and globulin increased slightly and the amount of albumin decreased slightly after vaccination compared to pre-vaccination $(P>0.05)$.

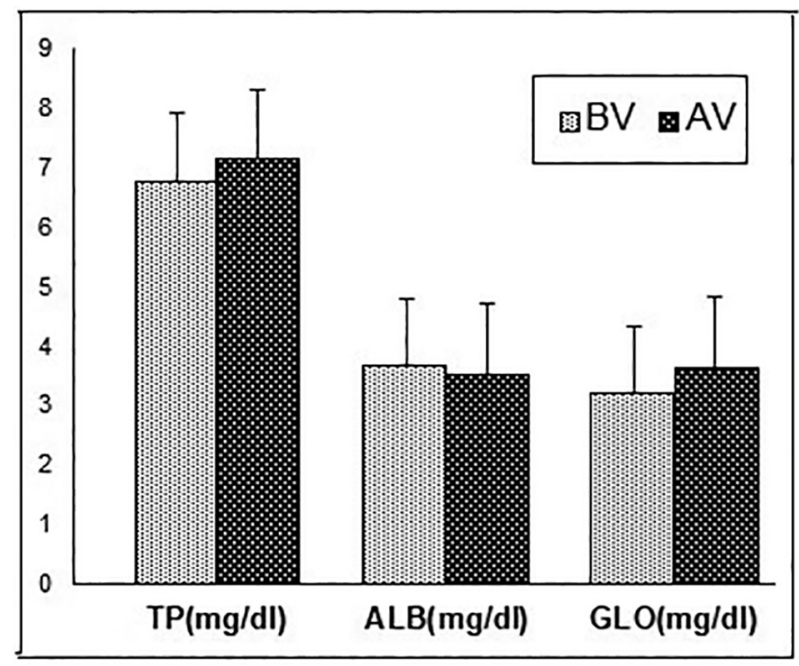

Figure 1. The mean \pm standard deviation (SD) levels of measured total protein (TP), albumine (ALB), globulin in sera obtained from before (BV) and after vaccination (AV).

Protein profile was investigated by SDS- and Native-PAGE methods. It was determined that there was no difference in protein profiles before and after vaccination by SDS- PAGE (Figure 2). In Native - PAGE method, albumin, alpha-1 globulin, alpha-2 globulin, beta globulin and gamma globulin profiles were investigated. After vaccination, it was determined that the albumin band density decreased slightly and the gamma globulin band density increased slightly compared to the prior vaccination (Figure 3).

\section{Serum total antioxidant, total oxidant level measurement and oxidative stress index}

The mean and standard error values of total antioxidant, total oxidant and oxidative stress index values in sheep pre- and postvaccinations are presented in the table (Table 1). It was determined that TAS level decreased after conjunctival vaccination in sheep, which was statistically significant $(P<0.05)$, and total oxidant and oxidative stress index increased slightly $(P>0.05)$ (Figure 4). 


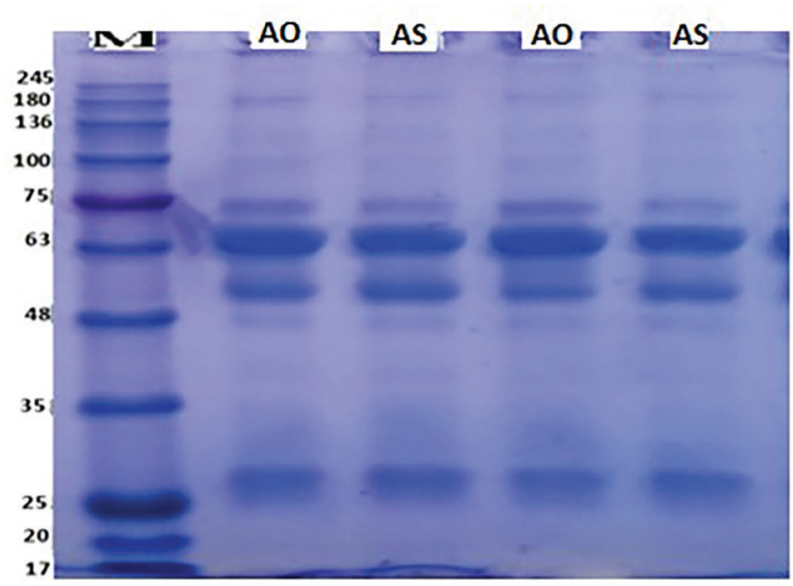

Figure 2. The protein profiles of serum taken before (BV) and after vaccination (AV) by SDS-PAGE.

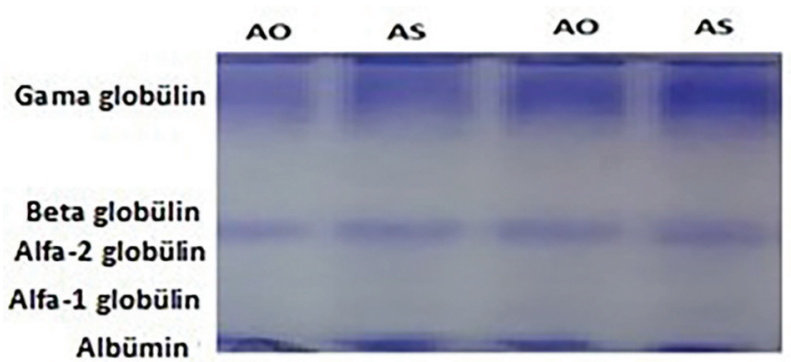

Figure 3. The protein profiles of serum taken before (BV) and after vaccination (AV) by Native-PAGE.

Table 1. The average levels of TAS, TOS and OSI in pre- (BV) and postvaccinated (AV) sheep.

\begin{tabular}{cccc}
\hline & TAS (mmol/L) & TOS (micromol/L) & OSI (AU) \\
\hline BV & $2.13 \pm 0.18$ & $22.99 \pm 2.14$ & $0.1 \pm 0.009$ \\
AV & $1.39 \pm 0.11$ & $27.65 \pm 2.91$ & $0.2 \pm 0.021$ \\
P & 0.001 & 0.516 & 0.104 \\
\hline
\end{tabular}

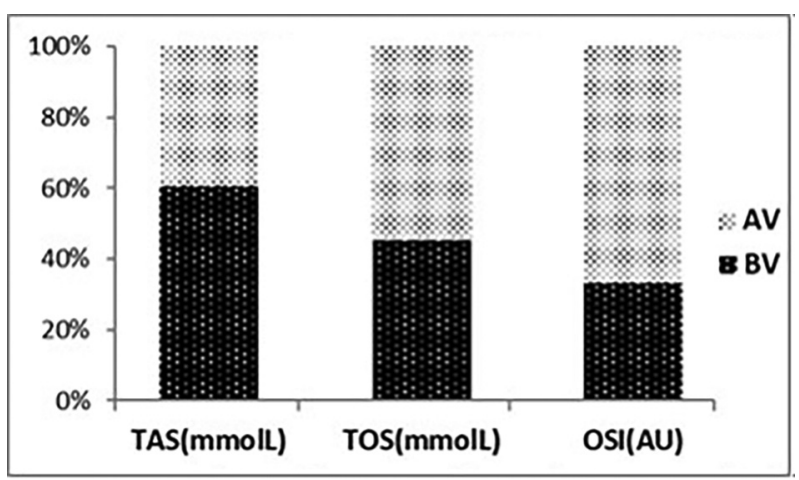

Figure 4. The percentages of TAS, TOS and OSI in pre- (BV) and post vaccinated (AV) sheep

\section{Discussion and Conclusion}

Brucellosis is a serious infectious disease that causes direct and indirect economic losses for animal owners around the world, such as reduction of milk and meat production through abortions/culling of positive reactors, disease control / eradication expenses and compensation for farmers. While eradication of brucellosis has been an important economic value, it is important for treatment purposes to determine its biochemical and cellular changes (Polycarp et al. 2017).

The microorganisms have different enzymatic and non-enzymatic antioxidant systems in place to protect against the harmful effects of reactive oxygen species. Antioxidant mechanisms are compromised under certain conditions and/or increases in ROS, and antioxidant mechanisms may be inadequate to avoid oxidative damage altogether and as a result, oxidative stress may evolve (Aruoma 1996; Halliwell and Gutteridge 1999). Specific plasma antioxidants influence the oxidant state and, in conjunction with antioxidants, shield it from the harmful effects of free radicals (Wayner et al. 1987). In our study, TAS ability in sheep with Rev. 1 conjunctival vaccine was found to decrease significantly compared to prevaccination, and this was statistically significant $(P<0.05)$, whereas total oxidant and oxidative stress index increased marginally and this was not statistically significant $(P>0.05)$. Serefhanoglu et al. (2009) reported that TAC levels in people infected with Brucella decreased dramatically, while malondialdehyde, total peroxide and oxidative stress index parameters increased (Serefhanoglu et al. 2009; Al-Khafaji and Al-Farwachi 2012). TAC values were found to be statistically significantly lower and TOC and OSI values were found to be significantly higher, compared to the control group reported in cattle with brucellosis (Karaagac et al. 2011; Merhan et al. 2017). Brucella abortus-infected cattle reported exposure of Brucella-infected bugs to oxidative stress (Kataria et al. 2012; Perin et al. 2017).

Blood serum or plasma is a blood fluid which sometimes changes as an active component invades the blood. Albumin and immunoglobulins are approximately 99 percent of the plasma proteins. The quantity of low serum or plasma proteins varies from $\mathrm{pg} / \mathrm{mL}$ to $\mathrm{ng} / \mathrm{mL}$ (Anderson and Anderson 2002). The level of serum protein is a critical component of animal laboratory diagnostic assessments. The increase in the total amount of protein may be due to the increase in the amount of 
albumin or globulin, or may be increased because both are increased together. Hamada et al. (2013) reported that between healthy sheep and Brucellainfected sheep, there was no statistically significant difference between total protein and albumin levels. El-Boshy et al. (2009) reported a significant decrease in the serum albumin content of healthy camels compared to camels infected with Brucella. It was determined that the amount of total protein and globulin increased slightly and that the amount of albumin in sheep with the conjunctival brucellosis vaccine Rev. 1 decreased slightly compared to before vaccination $(P>0.05)$. A small rise in the total protein level was thought to be due to an improvement in the level of gamma globulin.

The protein profile was evaluated using the SDS-PAGE and Native-PAGE methods. It was determined that there was no band difference in the SDS-PAGE method in serums of pre- and postvaccinated animals. The band density found as increased slightly after vaccination. Albumin, $\alpha 1$, $\alpha 2, \beta 1, \beta 2$ and $\boldsymbol{\gamma}$ globulins were determined by the Native-PAGE method. Following vaccination, the band intensity of the $\boldsymbol{\gamma}$ globulin band increased significantly compared with before vaccination. Albumin, $\alpha 1, \alpha 2, \beta 1$ and $\beta 2$ globulins were observed not to have changed significantly. Gamma globulin band density has been reported to have increased significantly in cows infected with Brucella, sheep, camel and cows (El-Boshy et al. 2009; Hamada et al. 2013; Nath et al. 2014; Eilazab 2015). It has been stated that, in response to chronic antigenic stimulation, the increase in globulin fraction in chronic or subacute bacterial infections may result from the development of various immunoglobulins by plasma cells (Morag 2002).

Conjunctival Rev.1 vaccine in seropositive sheep compared to non-vaccinated has been thought to be significantly affected and a decrease of overall antioxidant levels. In conclusion, Rev.1 conjunctival Brucella vaccine can be used for protection against Brucella in a safe manner.

Ethical statement: This work was carried out in accordance with the Ethics Committee Decision of the Ondokuz Mayıs University Local Ethics Committee Decision (2013/44).

Conflict of Interest: The authors have no conflicts of interest to declare.

\section{References}

Al-Khafaji WS, Al-Farwachi MI. (2012). Antioxidant status in pregnant ewes vaccinated with Rev.1 against brucellosis. Iraqi J Vet Sci. 26(1), 15-19.

Alton GG, Elberg SS. (1967). Rev.1 Brucella melitensis vaccine, a review of the 10 years of study. Vet Bull. 37, 793-800.

Anderson NL, Anderson NG. (2002). The human plasma proteome: history, character, and diagnostic prospects. Mol Cell Prot. 1(11), 845-867.

Aruoma OI. (1996). Characterization of drugs as antioxidant prophylactics. Free Rad Biol Med. 20, 675-705.

Blasco JM. (1997). A review of the use of Brucella melitensis Rev.1 vaccine in adult sheep and goats. Prev Vet Med. 31, 275-283.

Candiano G, Bruschi M, Musante L, Santucci L, Ghiggeri GM, Carnemolla B, Orecchia P, Zardi L, Righetti PG._(2004). Blue silver: a very sensitive colloidal Coomassie G-250 staining for proteome analysis. Electrophoresis. 25(9), 1327-1333.

Celi P, Gabai G. (2015). Oxidant/antioxidant balance in animal nutrition and health: The role of protein oxidation. Front Vet Sci. 2, 1-13.

Çiftci G, Yiğit Ö, Çiftci A. (2019). The effects of the conjunctival Brucella vaccine on some biochemical parameters in sheep. Trop Anim Health Prod. 51, 355-361.

Diaz Aparicio E. (2013). Epidemiology of brucellosis in domestic animals caused by Brucella melitensis, Brucella suis and Brucella abortus. Rev Sci Technol. 32(1), 53-60.

Dieffenbach CW, Tramont EC. (2005). Innate (general or nonspecific) host defense mechanisms. In: Mandell GL, Bennett JE, Dolin R (eds). Principles and Practice of Infectious Diseases. Sixth edition. Elsevier Churchill Livingstone, Philadelphia; pp.34-42.

Eilazab MFA. (2015). Evaluation of serum enzyme activities and protein fractions in Brucella-infected cows. Turk J Vet Anim Sci. 39, 480-484.

El-Boshy M, Abbas M, El-Khoderyl H, Osman S. (2009). Cytokine response and clinicopathological findings in Brucella infected camels (Camelus dromedarius). Vet Med. 54, 25-32.

Erdogan S, Aslantas O, Celik S, Atik E. (2007). The effects of increased CAMP content on inflammation, oxidative stress and PDE4 transcripts during Brucella melitensis infection. Res Vet Sci. 82, 181-186.

Erel O. (2004). A novel automated direct measurement method for total antioxidant capacity using a new generation, more stable ABTS radical cation. Clin Biochem. 37(4), 277-285.

Erel O. (2005). A new automated colorimetric method for measuring total oxidant status. Clin Biochem. 38(12), 11031111.

Halliwell B, Gutteridge JM. (1999). Free radicals in biology and medicine, 3rd ed., London: Oxford Science Publications.

Hamada DM, Mohamed AH, Mabrouk A, Emad M, Ah ME. (2013). Seroprevalence of abortion causing agents in Egyptian sheep and goat breeds and their effects on the animal's performance. J Agricult Sci. 5, 92-101.

Hornback ML, Roop RM. (2006). The Brucella abortus xthA-1 gene product participates in base excision repair and resistance to oxidative killing but is not required for wild-type virulence in the mouse model. J Bacteriol. 188, 1295-1300.

Kaplan M. (1966). The problems of choice between control and eradication. Joint WHO/FAO Expert Committee Zoonoses, Geneva, Dec.6-12. 
Karaagac L, Koruk ST, Koruk I, Aksoy N. (2011). Decreasing oxidative stress in response to treatment in patients with brucellosis: could it be used to monitor treatment? Int J Infect Dis. 15, e346-e349.

Kataria N, Kataria AK, Joshi A, Pandey N, Khan S. (2012). Serum Antioxidant Status to Assess Oxidative Stress in Brucella Infected Buffaloes. J Stress Physiol Biochem. 8, 5-9.

Kim JA, Sha Z, Mayfield JE. (2006). Regulation of Brucella abortus catalase. Infect Immun. 68, 3861-3866.

Laemmli UK. (1970). Cleavage of the structural proteins during the assembly of the head of bacteriophage T4. Nature. 227, 680-685.

Marzetti S, Carranza C, Roncallo M, Escobar GI, Lucero NE. (2013). Recent trends in human Brucella canis infection. Compar Immunol Microbiol Infect Dis. 36, 55-61.

Merhan O, Bozukluhan K, Kuru M, Büyük F, Özden Ö, Kükürt A. (2017). Investigation of Oxidative Stress Index and Lipid Profile in Cattle with Brucellosis. J Kafkas Univ Vet Fac. 23(6), 933-937.

Morag GK. (2002). Veterinary Laboratory Medicine, Clinical Biochemistry and Haematology. 2nd ed. Oxford, UK: Blackwell Science Ltd,

Nath R, Das S, Sarma S, Devi M. (2014). Comparison of blood profiles between healthy and Brucella affected cattle. Vet World. 7(9), 668-670.

Nisbet C, Yarim GF, Ciftci A, Cenesiz S, Ciftci G. (2007). Investigation of serum nitric oxide and malondialdehyde levels in cattle infected with Brucella abortus. Vet J Ankara Univ. 54(3), 159163.

Oral H, Ogun M, Kuru M, Kaya S. (2015). Evaluation of certain oxidative stress parameters in heifers that were administered short term PRID. J Kafkas Univ Vet Fac. 21, 569-573.

Orem A, Efe H, Deger O, Cimsit G, Uydu HA, Vanizor B. (1997). Relationship between lipid peroxidation and disease activity in patients with Behcet's disease. J Dermatol Sci. 16, 11-16.
Parish CR, Marchalonis JJ. (1970). A simple and rapid acrylamide gel method for estimating the molecular weights of proteins and protein subunits. Anal Biochem. 34(2), 436-450.

Perin G, Fávero JF, Severo DRT, Silva AD, Machado G, Araújo HL, Lilenbaum W, Morsch VM, Schetinger MRC, Jordão RS, Stefani LM, Bottari NB, Da Silva AS. (2017). Occurrence of oxidative stress in dairy cows seropositives for Brucella abortus. Microb Pathogen. 29, 196-201.

Polycarp TN, Yusoff SM, Benjamin EO, Salisi SM, Khairani S. (2017). Influence of dexamethasone-induced stress on oxidative stres biomarkers in non-pregnant does experimentally infected with Brucella melitensis. Compar Clin Pathol. 26, 423-435.

Rada B, Hably C, Meczner A. (2008). Role of Nox2 in elimination of microorganisms. Sem Immunopathol. 30, 237-253.

Revappayya M, Basavaraj A, Shambulingappa BE, Surya Prasad V, Abhilash B, Srinivas K. (2017). Evaluation of safety and immunogenicity of Brucella melitensis Rev.1 vaccine administered through Conjunctival route in sheep and goats. Int J Biol Sci. 8(2), 103-107.

Serefhanoglu K, Taskin A, Turan H, Timurkaynak FE, Arslan $\mathrm{H}$ Erel O. (2009). Evaluation of Oxidative Status in Patients with Brucellosis. Braz J Infect Dis. 13(4), 249-251.

Shome R, Gupta VK, Rao KN, Shome BR, Nagalingam M, Rahman H. (2014). Detection of Brucella melitensis Rev.1 vaccinal antibodies in sheep in India. Adv Anim Vet Sci. 2(3S), 19-22.

Usta M, Aras Z, Tas A. (2012). Oxidant and antioxidant parameters in patients with Brucella canis. Clin Biochem. 45, 366-367.

Vladimirov YA. (2004). Reactive oxygen and nitrogen species diagnostic, preventive and therapy. Biochem. 69(1), 57.

Wayner DD, Burton GW, Ingold KU. (1987). The relative

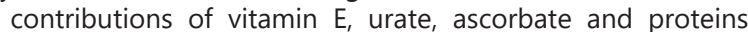
to the total peroxyl radical-trapping antioxidant activity of human blood plasma. Biochim Biophys Acta. 924, 408-419.

World Health Organisation. (1986). Joint FAO/WHO Expert Committee on Brucellosis, Sixth Report, Geneva, pp. 74-75. 